\title{
Winter Broccoli and Cauliflower under Organic High Tunnels in a Humid, Subtropical Climate
}

\author{
Suzanne O'Connell' ${ }^{1}$ and Robert Tate \\ Department of Horticulture, University of Georgia, 1111 Miller Plant \\ Sciences, Athens, GA 30602
} Additional index words. hoop house, brassica, season extension, local, plasticulture, protected
environment

\begin{abstract}
There is a lack of information related to adapting high tunnel systems to humid, subtropical climates in the Southeastern United States, resulting in a disadvantage for their use to extend growing seasons and meet the increasing demand for local horticulture products. This research project explored the possibility of growing organic broccoli and cauliflower (Brassica oleracea $L$.) under high tunnels during two consecutive fall/winter seasons in northeast Georgia (USDA plant hardiness zone 8a), particularly evaluating questions related to crop feasibility, planting dates and cultivar choices. Marketable yields for high tunnel broccoli ranged from $\approx \mathbf{1 1 , 8 0 0}$ to $15,800 \mathrm{~kg} \cdot \mathrm{ha}^{-1}$ and were not consistently affected by either planting date or cultivar type. Broccoli required an additional 8-45 days to reach maturity compared with seed catalog estimates with harvesting occurring during mid-December to mid-January. Marketable yields for high tunnel cauliflower ranged from $\approx 8600$ to $26,000 \mathrm{~kg} \cdot \mathrm{ha}^{-1}$ and were affected primarily by the cultivar type. Cauliflower required an additional 19-56 days to mature with harvesting occurring during the entire month of January. The first season was cooler than the second with the lowest growing degree days (GDD) units accumulated during the months of January and February. Differences in air temperature at the crop canopy between the high tunnel system and open field were largely related to high tunnel ventilation protocols that changed as the season progressed. An average heat gain of 7 to $8{ }^{\circ} \mathrm{C}$ under the high tunnels at crop canopy height was documented on the coldest days and an average of $1{ }^{\circ} \mathrm{C}$ gain on the warmest days compared with the open field. Overall, winter broccoli appeared more adaptable to high tunnels than cauliflower but production of both crops may be possible if planting dates and cultivar types are taken into account for the region.
\end{abstract}

High tunnels are plastic-covered, greenhouses where crops are typically grown in the soil and the temperature is passively managed (e.g., ventilation, shadecloth, heat sinks, insulation, etc.) (Wells and Loy, 1993; Wittwer and Castilla, 1995). The popularity of high tunnels has been growing steadily in the United States (Carey et al., 2009; Hochmuth and Toro, 2014). Using high tunnels allows farmers to reduce weather-related risks; improve product quality and consistency; assist with organic growing efforts; and be productive on limited amounts of land, amplify season extension opportunities, or both (Carey et al., 2009; Lamont, 2009; O'Connell et al., 2012). Since 2010, competitive cost-share programs administered by the Natural Resource

Received for publication 11 July 2017. Accepted for publication 19 Sept. 2017.

We are grateful for the funding provided by a private foundation that wishes to remain anonymous and from the University of Georgia. We also like to acknowledge the valuable assistance of Theekshana Jayalath, Ryan McNeill, Carl Hall and critiques from peer reviewers.

${ }^{1}$ Corresponding author. E-mail: soco@uga.edu.

This is an open access article distributed under the CC BY-NC-ND license (http://creativecommons. org/licenses/by-nc-nd/4.0/). elevation. From mid-November to midMarch, the hours of daylight range from $\approx 10$ to $12 \mathrm{~h}$ with a daily light integral (DLI) ranging from 15 to $35 \mathrm{~mol} \cdot \mathrm{m}^{-2} \cdot \mathrm{d}^{-1}$ (Korcyznski et al., 2002; USNO, 2015). There is a lack of information about the minimum average DLI required for many fruit or vegetable crops but the predicted temperatures indicate that many opportunities to grow and/or hold crops under high tunnels in the Southeast during the fall/winter season is possible. This is different from, for example in Maine, where less than $38 \%$ of high tunnel growers plant winter crops (Fitzgerald and Hutton, 2012). Typical high tunnel crops grown in the Southeast during the fall/winter season include salad and cooking greens, root crops, alliums, and overwintered flowers. It is unclear, if these choices reflect information from cooler or more lightlimited regions which have influenced high tunnel grower crop choices or if they are related to profitability (i.e., customer demand, quick turnover, etc.).

The following studies have evaluated high tunnel use for fruit and vegetable production in the humid, subtropical areas documenting benefits and challenges associated with their use. A strawberry study conducted in FL found $54 \%$ greater yields and marketable fruit weight $69 \%$ greater under high tunnels compared with open field production (Salame-Donoso et al., 2010). In NC, differences among strawberry cultivars correlated with greater yields under high tunnels indicating the importance of crop and cultivar selection (Gu et al., 2017). An organic tomato study in $\mathrm{NC}$ found that heirlooms grown under high tunnels in the spring and summer had equal or greater yields depending on the year, and they were consistently harvested three weeks earlier than the field (O'Connell et al., 2012). In GA, organic spring lettuce yields were equal or greater for a high tunnel system compared with the field depending on the year and were 2-7 d earlier (Jayalath, 2016). An early spring lettuce crop in TN achieved not only greater total yields under high tunnels compared with the field but the crop was also subject to more pest, disease, and physiological damage, reducing marketability of the crop (Wallace et al., 2012). Two studies (GA and NC) found that early blooming of small fruits (i.e., strawberry and Southern highbush blueberry) under high tunnels may increase frost damage and fruit abortion because of early bloom times ( $\mathrm{Gu}$ et al., 2017; Ogden and van Iersel, 2009). Overall, high tunnels appear to offer a benefit in the region but yearly weather conditions, structure/system characteristics, cultivar selection, and crop sensitivity to fluctuating temperatures may affect potential yield gains.

Informally interviewed high tunnel growers, in the same climate and hardiness zone as our research project, indicated that they would be interested in integrating other crops into their fall/winter portfolio. This would help meet growing year-round and winter holiday market demand for local and 
organic produce and help expand crop rotation options (Celia Barss, Nicholas Donck and Jay Payne, personal communication, Summer 2015). The National Farmers Market Directory also reports the rapid growth of winter markets (USDA, 2012b).

Open-field broccoli and cauliflower are generally planted in the late summer or early fall and harvested during the months of October and November in this area. The optimal temperatures for crop growth are 15 to $18^{\circ} \mathrm{C}$ while avoiding temperatures $\geq 30{ }^{\circ} \mathrm{C}$ (Heather et al., 1992; Maynard and Hochmuth, 2007). These temperature ranges indicate that growing broccoli and cauliflower during late fall and early winter under high tunnels would be possible although it is not typical. This schedule could lead to season extension opportunities from November through January. Therefore, this research project explored the possibility of growing atypical broccoli and cauliflower (Brassica oleracea L.) crops under high tunnels during the fall/winter season in northeast GA (Zone 8a). Specific objectives were to evaluate crop feasibility, planting dates, and cultivar choices.

\section{Materials and Methods}

A replicated comparison of multiple broccoli and cauliflower cultivars transplanted at two different fall planting dates and managed with certified organic practices under high tunnels was carried out over two growing seasons. Differences in crop yields and days to harvest after transplanting were evaluated while pest and disease issues were monitored. In addition, microenvironmental parameters inside and outside the high tunnels were compared.

Site background. The study was conducted at the University of Georgia, Durham Horticulture Research Farm located in Watkinsville, GA (lat. 33.88689 N, long. 83.41941 W) from 2014 to 2016. Soils at this site are categorized as a well-drained Cecil sandy loam soil that has been eroded overtime so that the plow layer now extends into the red sandy clay loam subsoil (CYB2) (NRCS-USDA, 1968). The project site has been certified organic since 2012, and all production methods were performed under the guidelines of the USDA National Organic Program certification standards (7 U.S.C. \$6501). There was no recent history of Brassicaceae crops in the project area before our study. Between the two brassica-growing seasons, a spring organic lettuce (Lactuca sativa) crop followed by a pearl millet (Pennisetum glaucum) cover crop was planted under both high tunnels. The pearl millet cover crop was mowed and incorporated into the soil using a tractormounted rotary tiller 1 month before transplanting the brassica crops.

Experimental design. Two snow-arch design high tunnels $(29.3 \times 9.1 \times 3.7 \mathrm{~m})$ were used for the experiment (Atlas Greenhouses Inc., Alapaha, GA). High tunnel features included bows every $1.8 \mathrm{~m}$, an inflated double polyethylene film roof $(0.15 \mathrm{~mm}$ thickness) (SunView4; Poly-Ag Corp., San
Diego, CA), twin-wall polycarbonate end walls, and an automated " $1.8 \mathrm{~m} \mathrm{Z}$-Lock drop-down curtain system" fabric side curtains $(0.3 \mathrm{~mm}$ thickness). The high tunnels were oriented east-west to minimize high tunnel surface area exposed to the prevailing westerly winter winds.

The experiment was a split-plot design and treatments were replicated four times (i.e., two blocks in each commercial-size high tunnel). The main plot was planting date and the subplot treatment was cultivar. In 2014, planting dates for both crops were 7 Oct. and 21 Oct. In 2015, planting dates were 22 Sept. and 6 Oct., 2 weeks earlier than the first season. Dates were modified in the second season to achieve a greater overlap of the harvest period during the months of November to January.

Four broccoli (Brassica oleracea var. italica) cultivars were evaluated: 'Belstar' and 'Fiesta' (High Mowing Seeds, Wolcott, VT), 'Imperial' and 'Marathon' (Johnny's Selected Seeds, Winslow, ME) and three cauliflower (Brassica oleracea var. botrytis) cultivars were evaluated including 'Amazing', 'Denali' (Johnny's Selected Seeds), and 'Snowball Y'(High Mowing Seeds). Cultivar choices were based on seed catalog descriptions promoting appropriateness for fall season production and similar days to harvest ( $\approx 65-75 \mathrm{~d})$.

Crop management and data collection were carried out by block. Both crops were grown in $0.9 \mathrm{~m}$ wide raised beds with an eastwest orientation. Each broccoli block consisted of one 3.4-m long row with $30.5 \mathrm{~cm}$ in-row spacing for a total of 11 plants per experimental unit. Each cauliflower block consisted of one 4.6-m long row with $45.7 \mathrm{~cm}$ in-row spacing for a total of nine plants per experimental unit. Footpaths in between rows were $30.5 \mathrm{~cm}$ wide. If extrapolated to 1 ha for each crop, there was a planting density of 25,000 broccoli plants/ha $\left(0.28 \mathrm{~m}^{2} /\right.$ plant $)$ and 16,667 cauliflower plants/ha $\left(0.42 \mathrm{~m}^{2} /\right.$ plant $)$. This assumes that $\approx 70 \%$ of the available area was planted with crops and $30 \%$ devoted to foot paths, work spaces, etc. under the high tunnels. Blocks were rerandomized each year and guard rows were included on lateral sides of each high tunnel to minimize edge effects from sun, wind, etc.

Transplants were grown onsite in a heated greenhouse maintained at 13 to $20^{\circ} \mathrm{C}$ nighttime/day-time temperatures. Seeds were sown into 36-cell packs (L-606; Landmark Plastic Corp., Akron, OH) filled with potting soil (Sunshine Natural \& Organic Mix \#1; Sun Gro Horticulture, Agawam, MA). Overhead irrigation was administered by hand as needed. A soluble fish and seaweed fertilizer (AgGrand Organic Series (4N-1.3P-2.5K); Amsoil, Inc., Superior, WI) was applied once per week during the third and fourth week after seeding at a rate of $8 \mathrm{~mL} \cdot \mathrm{L}^{-1}$ of water. Seedlings were acclimated to the outside environment 1 week before transplanting to the high tunnels. Seedlings were transplanted when they were 4 weeks old.
Black polypropylene landscape fabric $\left(109 \mathrm{~g} \cdot \mathrm{m}^{-2}\right)$, secured with metal fabric pins was used as a weed barrier and heat sink. Holes were cut into the fabric to accommodate the broccoli and cauliflower transplants. Irrigation was administere for $\approx 60-90 \mathrm{~min}$ per cycle every 2-4 d, depending on the growth stage of plants and weather conditions. There was one drip tape with emitters every $20 \mathrm{~cm}$ and a flow rate of $1.3 \mathrm{lpm}$ per $31 \mathrm{~m}$ per planted row (Chapin Tape; JainUSA, Watertown, NY).

During the growing season, sidewall curtain and end walls were opened and closed with consideration of the air temperature, precipitation, and wind speed. Dropdown sidewall curtains were lowered (i.e., opened) when ambient air temperatures inside the tunnels at $1.8 \mathrm{~m}$ above the soil line exceeded $15.6 \pm 1{ }^{\circ} \mathrm{C}$. The side curtain threshold temperature was chosen based on the optimum growth temperatures for brassica crops (15 to $\left.18^{\circ} \mathrm{C}\right)$. When rain or strong winds $(>24 \mathrm{kph})$ occurred the side and/or end walls were closed as long as the high tunnel temperature was not predicted to surpass $26^{\circ} \mathrm{C}$. This protocol was necessary to keep roof/sidewall runoff from flooding the high tunnel soil, rain blowing into the tunnels, andstrong winds from damaging the plants or side wall curtains.

One layer of intermediate weight rowcover (i.e., 41 g.m ${ }^{-2}$ ) ('Gro-Guard \#40'; Atmore Industries, Atmore, AL) was hung over wire hoops to create a low tunnel over the plants when the nighttime temperatures were predicted to be $\leq 0{ }^{\circ} \mathrm{C}$. The low tunnel apex was $\approx 1 \mathrm{~m}$ above the soil line. Row cover edges were held in place with weighted sand bags. Placement of rowcovers were carried out during the late afternoon (4:00 to 6:00 PM) and removed the following morning (8:00 to 9:00 AM).

Pest management decisions were based on observations from biweekly scouting and treatment actions were based on established integrated pest management (IPM) thresholds for organic systems when available. The following products were used to manage pest and disease pressure: insecticidal soap for aphids (Brevicoryne brassicae and Macrosiphum euphorbia) (M-Pede; Dow AgroSciences, Indianapolis, IN), neem oil combined with insecticidal soap for whiteflies (Neem Concentrate; Green Light; San Antonio, TX), Bacillus thurigiensis for cabbage loopers (Trichoplusia ni) and cabbage worms (Artogeia rapae) (Dipel DF; Valent BioSciences Corp., Libertyville, IL), spinosad for fire ants (Entrust SC Naturalyte; Dow AgroSciences) copper hydroxide for gray mold (Botryis cinera) and downy mildew (Hyaloperonospora parasitica) (NuCop 50WP; Albaugh, Inc., Ankeny, IA), and snap traps for mice.

Soil amendment and fertilizer inputs. Fertilizer applications were the same for the broccoli and cauliflower crops. Preplant soil amendments and fertilizers used included compost, feathermeal, rock phosphate, potassium sulfate, boron, and lime (Table 1). Compost, lime (2014-15 only), nitrogen, and boron applications were consistent across 
all blocks. Phosphorus and potassium applications were different among blocks to bring them up to comparable levels; the differences among blocks were likely due to slight differences in soil texture (sandy loam to sandy clay loam) and percent organic matter ( $3 \%$ to $5 \%$ ). These differences may have been inherent or a result of high tunnel site preparation activities conducted in 2014 (i.e., grading soil to create level ground). Fertilizers were applied by block and shallowly incorporated.

Rates were based on using the low range of soil test recommendations from the UGA Agriculture and Environmental Services Laboratory (AESL) (Athens, GA). In 2014, the preplant fertilizer $\mathrm{N}$ rate was $157 \mathrm{~kg} \cdot \mathrm{ha}^{-1}$. About 6 weeks after planting, crops were side-dressed with an additional $45 \mathrm{~kg} \mathrm{~N} / \mathrm{ha}$ (Table 1). Plant tissue analysis conducted at the pre-heading stage for both broccoli and cauliflower indicated that the $\mathrm{N}$ concentrations were greater $(\approx 8 \%$ to $9 \%$ ) than the recommended range $(\approx 6 \%)$. Therefore, in 2015 , the pre-plant fertilizer $\mathrm{N}$ rate was decreased by $\approx 15 \%$ to $135 \mathrm{~kg} \mathrm{~N} / \mathrm{ha}$. In 2015, follow-up plant tissue analysis conducted at the preheading stage indicated that the $\mathrm{N}$ concentrations were lower than the previous year $(\approx 7 \%)$ but still $1 \%$ to $2 \%$ greater than the recommended range. The rate and timing of the side-dress fertilizer application was kept the same both years (Table 1).

Sampling protocols. Both broccoli and cauliflower were harvested twice per week. Broccoli was harvested twice per week between 30 Dec. 2014 to 16 Feb. in 2015 and 1 Dec. 2015 to 8 Jan. 2016. Cauliflower was harvested twice per week between 30 Dec. 2014 to 16 Feb. 2015 and 15 Dec. 2015 to 16 Feb. 2016. One head per plant was harvested when it appeared to reach a maximum size $(\approx 13-20 \mathrm{~cm})$ while maintaining good quality according to the USDA maturity standards for bunched broccoli [7 Code of Federal Regulations (CFR) §51.3555] and U.S. No.

Table 1. Soil amendments and fertilizer inputs for brassica crops.

\begin{tabular}{lll}
\hline Yr & \multicolumn{1}{c}{ Material } & \multicolumn{1}{c}{ Rate (dry wt) } \\
\hline 2014 & Calcitic lime & $2,242-4,483 \mathrm{~kg} \cdot h a^{-1}$ \\
& Rock phosphate $(0 \mathrm{~N}-3.0 \mathrm{P}-0 \mathrm{~K})^{\mathrm{z}}$ & $22-224 \mathrm{~kg} \cdot \mathrm{ha}^{-1}$ \\
& Potassium sulfate $(0 \mathrm{~N}-0 \mathrm{P}-41.5 \mathrm{~K})^{\mathrm{y}}$ & $157-213 \mathrm{~kg} \cdot \mathrm{ha}^{-1}$ \\
& Compost $(1 \mathrm{~N}-0 \mathrm{P}-0 \mathrm{~K})^{\mathrm{x}}$ & $22 \mathrm{t} \cdot \mathrm{ha}^{-1}$ \\
& Feathermeal $(13 \mathrm{~N}-0 \mathrm{P}-0 \mathrm{~K})^{\mathrm{w}}$ & $157 \mathrm{~kg} \cdot \mathrm{ha}^{-1}$ \\
& Boron $(10 \% \mathrm{~B})^{\mathrm{v}}$ & $2.2 \mathrm{~kg} \cdot \mathrm{ha}^{-1}$ \\
& Naturesafe $(10 \mathrm{~N}-0.9 \mathrm{P}-6.7 \mathrm{~K})^{\mathrm{u}}$ & $45 \mathrm{~kg} \cdot \mathrm{ha}^{-1}$ \\
& & \\
& & $118-168 \mathrm{~kg} \cdot \mathrm{ha}^{-1}$ \\
& Potassium sulfate $(0 \mathrm{~N}-0 \mathrm{P}-41.5 \mathrm{~K})^{\mathrm{y}}$ & $22 \mathrm{t} \cdot \mathrm{ha}^{-1}$ \\
& Compost $(1 \mathrm{~N}-0 \mathrm{P}-0 \mathrm{~K})$ & $135 \mathrm{~kg} \cdot \mathrm{ha}^{-1}$ \\
& Feathermeal $(13 \mathrm{~N}-0 \mathrm{P}-0 \mathrm{~K})$ & $2.2 \mathrm{~kg} \cdot \mathrm{ha}^{-1}$ \\
& Boron $(10 \% \mathrm{~B})$ & $45 \mathrm{~kg} \cdot \mathrm{ha}^{-1}$ \\
\hline
\end{tabular}

\footnotetext{
z“Calphos", Canton Mills, Inc.; Minnesota City, MN.

y "Great Salt Lake Mineral Corp, Sulfate of Potash"; Overland Park, KS.

"University of Georgia, Bioconversion Center Compost; Athens, GA.

w"Hydrolyzed Poultry Feathers", Mason City By-Products, Inc.; Mason City, IA.

v"Cameron Chemicals Boron 10\%"; Virginia Beach, VA.

u“Naturesafe All Season Fertilizer", Griffin Industries LLC; Cold Spring, KY.

Seventy percent of $\mathrm{N}$ was assumed to be available to crops.

Applied about 6 weeks after planting.
}

was an oat cover crop growing. GDD were calculated using the average daily temperature generated by monitoring stations minus the base temperature of $7.2{ }^{\circ} \mathrm{C}$ (Dufault, 1997).

Statistical analysis. The main factors of interest in this study were a comparison between two planting dates and either four broccoli cultivars or three cauliflower cultivars. Therefore, the continuous response variables included in this dataset were marketable yield and average days to harvest. Individual marketable head fresh weight was obtained by dividing the total weight of marketable heads by the total number of marketable heads per plot. These variables were about normally distributed so the statistical analysis was carried out using a mixed effects analysis of variance model (SAS Institute, Cary, NC); the data did not require any transformation and block was considered a random effect. Tukey's mean separation method with $95 \%$ confidence level was used to determine if there were significant differences between planting dates or cultivar type for each crop. Each year was analyzed separately to account for different weather patterns.

The response variables related to nonmarketable yield (i.e., culls) were analyzed differently because they comprised small positive integers that were not continuous. A logistic regression model was used to predict the proportion of the total harvested heads that were non-marketable using planting date or cultivar type as explanatory variables for each crop type (SAS Institute). Block was considered a random effect. Each year was analyzed separately to account for different weather patterns.

Statistical analysis was not conducted on the microenvironmental data; however, the average daily and monthly values are presented (i.e., air temperature, soil temperature, relative humidity, and GDD). This provides a useful comparison between the high tunnel and field microenvironments across the growing season and between years at our research site as well as to compare with other regions conducting high tunnel research.

\section{Results}

Broccoli yield. The marketable yield ranged from $\approx 13,100$ to $15,800 \mathrm{~kg} \cdot \mathrm{ha}^{-1}$ in 2014-15 and 11,800 to $13,400 \mathrm{~kg} \cdot \mathrm{ha}^{-1}$ in 2015-16 (Table 2). In both growing seasons, the average marketable yield was unaffected by planting date. Differences among cultivars were evident in 2014-15 when 'Belstar' had a greater average weight per head compared with 'Marathon' but was not different from 'Fiesta' or 'Imperial' (Table 2). In addition to head weight, the diameter of each broccoli head was measured. Broccoli heads were informally categorized as small $(12.7-15.1 \mathrm{~cm})$, medium $(15.2-17.8 \mathrm{~cm})$, or large $(17.9-20.3 \mathrm{~cm})$ diameter. In $2014-15, \approx 65 \%$ of the broccoli heads for both planting dates were considered medium-sized or larger (Table 2). In 2015-16, the same was true for the first planting date but 
Table 2. Mean monthly air temperatures $\left({ }^{\circ} \mathrm{C}\right)$ for high tunnels compared with the open field, $2014-16$.

\begin{tabular}{|c|c|c|c|c|c|c|c|c|c|c|c|c|c|c|c|c|c|c|c|}
\hline \multirow{2}{*}{$\frac{\mathrm{Yr}}{2014-15}$} & \multirow[b]{2}{*}{ System } & \multicolumn{3}{|c|}{ Sept. $^{\mathrm{z}}$} & \multicolumn{3}{|c|}{ Oct. ${ }^{y}$} & \multicolumn{3}{|c|}{ Nov. } & \multicolumn{3}{|c|}{ Dec. } & \multicolumn{3}{|c|}{ Jan. } & \multicolumn{3}{|c|}{ Feb. ${ }^{x}$} \\
\hline & & Mean & Min & $\operatorname{Max}$ & Mean & Min & $\operatorname{Max}$ & Mean & Min & $\operatorname{Max}$ & Mean & Min & $\operatorname{Max}$ & Mean & Min & $\operatorname{Max}$ & Mean & Min & $\operatorname{Max}$ \\
\hline & High tunnel & & & & 18.4 & 12.1 & 26.5 & 11.3 & 5.8 & 20.0 & 10.3 & 5.3 & 17.0 & 8.0 & 2.3 & 15.2 & 8.6 & 1.4 & 18.0 \\
\hline & Field & & & & 17.0 & 9.6 & 25.2 & 7.9 & 1.0 & 16.1 & 8.4 & 2.6 & 14.3 & 5.2 & -1.3 & 11.0 & 4.8 & -3.0 & 11.3 \\
\hline & Diff. $(H T-F)$ & & & & 1.4 & 2.5 & 1.3 & 3.3 & 4.8 & 4.0 & 1.9 & 2.7 & 2.6 & 2.8 & 3.7 & 4.2 & 3.8 & 4.4 & 6.7 \\
\hline & & \multicolumn{3}{|c|}{ Sept. } & \multicolumn{3}{|c|}{ Oct. } & \multicolumn{3}{|c|}{ Nov. } & \multicolumn{3}{|c|}{ Dec. } & \multicolumn{3}{|c|}{ Jan. } & \multicolumn{3}{|c|}{ Feb. } \\
\hline $2015-16$ & & Mean & Min & $\overline{\operatorname{Max}}$ & Mean & Min & Max & Mean & Min & $\overline{\operatorname{Max}}$ & Mean & Min & $\overline{\operatorname{Max}}$ & Mean & Min & $\overline{\operatorname{Max}}$ & Mean & Min & $\overline{\operatorname{Max}}$ \\
\hline & High tunnel & 20.9 & 18.0 & 24.6 & 16.9 & 11.2 & 23.6 & 14.0 & 9.2 & 20.4 & 13.8 & 9.1 & 20.0 & 8.5 & 4.1 & 14.9 & 9.4 & 5.1 & $\overline{17.2}$ \\
\hline & Field & 20.7 & 17.6 & 24.0 & 15.8 & 9.7 & 22.6 & 13.0 & 7.7 & 18.6 & 12.7 & 7.3 & 18.8 & 5.0 & -0.1 & 11.0 & 6.0 & 0.6 & 12.4 \\
\hline & Diff. $(H T-F)$ & 0.2 & 0.4 & 0.6 & 1.1 & 1.5 & 1.0 & 1.0 & 1.5 & 1.8 & 1.1 & 1.8 & 1.2 & 3.5 & 4.2 & 3.9 & 3.4 & 4.5 & 4.8 \\
\hline
\end{tabular}

${ }^{\mathrm{z}}$ Represents period from 23 to 30 Sept. 2015.

${ }^{\mathrm{y}}$ Represents period from 8 to 31 Oct. 2014 and 1 to 31 Oct. 2015.

${ }^{\mathrm{x}}$ Represents period from 1 to 18 Feb. 2015 and 1 to 15 Feb. 2016.

only $55 \%$ were considered medium-sized or larger for the second planting date (Table 2). Both planting dates and all broccoli cultivars had high rates ( $87 \%$ to $98 \%$ ) of marketability (Table 2). During the 2014-15 season, rodent damage accounted for the greatest loss, until snap traps were deployed, compared with over-maturity in 2015-16 (Table 2).

The effect of planting date on broccoli days to harvest after transplanting was inconsistent across the two seasons. The seed catalog estimates for days to harvest were 65 , 68, 71, and $75 \mathrm{~d}$ for 'Belstar', 'Marathon', 'Imperial', and 'Fiesta', respectively. In 2014-15, an additional 21-45 d was required, and in 2015-16, an additional 8-21 d was required compared with the seed catalog estimates depending on the planting date and cultivar. During the 2014-15 season, the first planting date was an average of $10 \mathrm{~d}$ quicker to harvest than the second planting date (Table 2). In addition, 'Imperial' and 'Marathon' were $\approx 5 \mathrm{~d}$ earlier to harvest compared with 'Belstar' and 'Fiesta'. In 2015-16, both planting dates were earlier to mature than the previous season, and there were no significant differences among the average days to harvest $(\approx 84-85 \mathrm{~d})$ (Table 2$)$. Across both years, the only consistent significant interaction was between the first planting date and cultivar type which indicated that 'Imperial' matured $\approx 1$ week earlier than 'Belstar' or 'Fiesta' broccoli $(P<0.03)$.

Cauliflower yield. The marketable yield ranged widely from $\approx 8600$ to $26,000 \mathrm{~kg} \cdot \mathrm{ha}^{-1}$ in 2014-15 and 9300 to $23,300 \mathrm{~kg} \cdot \mathrm{ha}^{-1}$ in 2015-16 (Table 3). During both growing seasons, the average marketable yield was unaffected by planting date but cultivar type had a significant effect on crop yields. 'Denali' had a greater average marketable yield compared with 'Snowball Y' across both growing seasons, and 'Denali' was also greater than 'Amazing' in 2014-15 (Table 3).

In addition to weight, the diameter of each cauliflower head was measured. Most were informally categorized as large (15.2-17.8 $\mathrm{cm})$ or $x$-large $(17.9-20.3 \mathrm{~cm})$. The average cauliflower head diameter did not appear to be affected by planting date or cultivar type (Table 3). Across both seasons, 'Denali' and 'Amazing' had high rates of marketable heads $(90 \%$ to $99 \%$ ) but only $\approx 50 \%$ to $60 \%$ of 'Snowball Y' were considered marketable
(Table 3). During both seasons, bracting and riciness which were both categorized as "overmature" accounted for the greatest losses followed by the "other" category which included buttoning and the failure to form a head (Table 3).

Cultivar affected the number of days to harvest after transplanting in the following ascending order: 'Amazing' (87-99 d), 'Denali' (93-107 d), and 'Snowball Y' $(113-126 \mathrm{~d})(P<0.0001)$. All cultivars required additional days to harvest compared with seed catalog estimates which were 68 , 73, and $70 \mathrm{~d}$ for 'Amazing', 'Denali', and 'Snowball Y', respectively. During 2014-15, an additional 31-43 d to harvest was required, and in 2015-16, an additional 19$56 \mathrm{~d}$ to harvest was required compared with seed catalog estimates. The only significant interaction between planting date and cultivar type was in 2015-16, when the first planting date of 'Snowball Y' cauliflower was 2 weeks slower to mature than the second planting date $(P<0.0001)$.

Microenvironmental monitoring. In general, the 2014-15 season was cooler than the 2015-16 season (Table 4). Row covers were used as an added layer of cold protection on nights predicted to be $\leq 0{ }^{\circ} \mathrm{C}$. Therefore, rowcovers were used to cover the crops $\approx 50$ times in the 2014-15 season compared with $\approx 30$ times in the $2015-16$ season due to frost predictions. The difference in temperature between the two seasons was also reflected in the estimated GDD. The GDD under the high tunnels were $\approx 340$ units lower for the first compared with the second growing season (Table 5). The accumulation of GDD was the lowest during the months of January and February both years (Table 5).

The average daily air temperature across the growing season under the high tunnels was $\approx 1$ to $4{ }^{\circ} \mathrm{C}$ warmer than the field at the crop canopy height (Table 4). In October at the beginning of the growing season, when temperatures were still warm and when the high tunnels were often fully vented, the average daily air temperature was $\approx 1{ }^{\circ} \mathrm{C}$ warmer under the high tunnels than the field (Table 4). The greatest heat gains were during the coldest months of January and February when the high tunnels were vented less frequently (Table 4). On the coldest days of each season, the high tunnels maintained a daily average temperature $\approx 7$ to $8{ }^{\circ} \mathrm{C}$ warmer than the field (Table 4). The absolute minimum air temperatures $(\approx 7: 00 \mathrm{AM})$ during the experiment were 3 to $4{ }^{\circ} \mathrm{C}$ warmer under the high tunnels compared with the field.

Soil temperatures demonstrated similar trends with air temperatures. The average daily soil temperature under the high tunnels ranged from $\approx 3$ to $7^{\circ} \mathrm{C}$ greater than the field across both growing seasons. Figure 1 shows data from the 2014-15 season (i.e., colder season). The average daily soil temperature rarely went below $10{ }^{\circ} \mathrm{C}$ under the high tunnels, and neither the high tunnel nor the field system soil dropped below $3{ }^{\circ} \mathrm{C}$ during the growing season (Fig. 1). The relative humidity of both the high tunnel and field systems was about the same when the high tunnels were fully vented during the beginning of the season. Figure 2 shows data from the 2015-16 season (i.e., the wetter season). Later in the winter season, when high tunnels were closed up more frequently for rain events or cold, the daily average relative humidity in the high tunnels was greater than the open field (Fig. 2). For most of the season, daily average relative humidity levels under the high tunnels ranged from $70 \%$ to $100 \%$.

\section{Discussion}

Broccoli yield. Differences among planting dates and cultivar type did not appear to have a major or consistent influence on the average marketable yield of fall/winter broccoli grown under our high tunnel system, although the cultivar 'Imperial' was slightly quicker to mature $(\approx 1$ week) compared with 'Belstar' and 'Fiesta'. In addition, all planting dates and cultivars demonstrated a high percentage of marketability, and our yields were equal or greater than another organic open field broccoli study conducted at the same location in Georgia (Boyhan et al., 2016). There were no indications of damage to the either broccoli or cauliflower heads grown under the high tunnels because of cold temperatures during the experimental timeframe, although some leaf tissue showed signs of frost damage later in the season.

Planting dates ranging from midSeptember to late-October seemed feasible in terms of achieving a high quality crop that 
could be harvested from December through January (i.e., 85-100 d after transplanting), although this depends on weather conditions and high tunnel and crop management protocols. The diversity of high tunnel structures and management strategies makes comparing study results challenging. Such comparisons would be very valuable to provide guidance to regional high tunnel growers.

The average broccoli harvest dates during the 2014-15 season were in the middle of January and the beginning of February. Because we thought there would be financial benefits to both, an earlier crop maturity and greater overlap with winter holiday markets, we advanced our planting dates by 2 weeks in the 2015-16. As a result, in the second season, the average broccoli harvest dates coincided with the middle and end of December; however, a confounding factor was that 2015-16 was also a warmer season. The average days to harvest was longer than seed catalog estimates $(\approx 10-40 \mathrm{~d}$ longer $)$ depending on the year, planting date, and cultivar which is something to consider for fall/winter crop planning.

The average broccoli yield was lower in 2015-16, and this appeared to correspond with an increasing incidence of loose or flowering buds (i.e., indicator of heat stress)

Table 3. Monthly growing degree days under high tunnels by season.

\begin{tabular}{lccccccr}
\hline Season & September $^{\mathrm{y}}$ & October $^{\mathrm{x}}$ & November & December & January & February $^{\mathrm{w}}$ & Total \\
\hline $2014-15$ & $\mathrm{n} / \mathrm{a}$ & 290 & 171 & 122 & 53 & 47 & 683 \\
$2015-16$ & 113 & 317 & 228 & 228 & 78 & 61 & 1,025 \\
Diff. (between two seasons) & 113 & 27 & 57 & 106 & 25 & 14 & 342 \\
\hline
\end{tabular}

${ }^{\mathrm{z}}$ Growing degree days $=\left[\left(\right.\right.$ average daily temp. $\left.{ }^{\circ} \mathrm{C}\right)-\left(\right.$ base temp. of $\left.\left.7.2{ }^{\circ} \mathrm{C}\right)\right]$.

${ }^{\mathrm{y}}$ Represents period from 23 to 30 Sept. 2015.

${ }^{\mathrm{x}}$ Represents period from 8 to 31 Oct. 2014 and 1 to 31 Oct. 2015.

${ }^{\mathrm{w}}$ Represents period from 1 to 18 Feb. 2015 and 1 to 15 Feb. 2016.

that affected our harvest decisions. Broccoli heads showing early signs of loose or flowering buds were harvested twice a week and categorized as marketable or non-marketable depending on the severity of physiological disorders. Harvesting more frequently likely would have reduced the number of heads that were deemed non-marketable. The impact of heat units and fluctuating temperatures on maturity dates, cultivar selection, and physiologic disorders for broccoli under high tunnels is a topic that would benefit from further exploration. Also, we chose to maximize head size (i.e., dinner-plate size) before harvesting, but many growers choose to harvest smaller heads and then return to cut subsequent side shoots (Sanchez et al., 2016); this decision impacted our days to harvest and total yield estimates.

Broccoli was about 2 weeks slower to mature in 2014-15 compared with 2015-16. This delay is likely attributable to colder growing temperatures and lower accumulation of GDD during the first growing season compared with the second season. It is impossible to evaluate whether temperature

Table 4. Comparison of mean broccoli yield and days to harvest under a tunnel system, 2014-16.

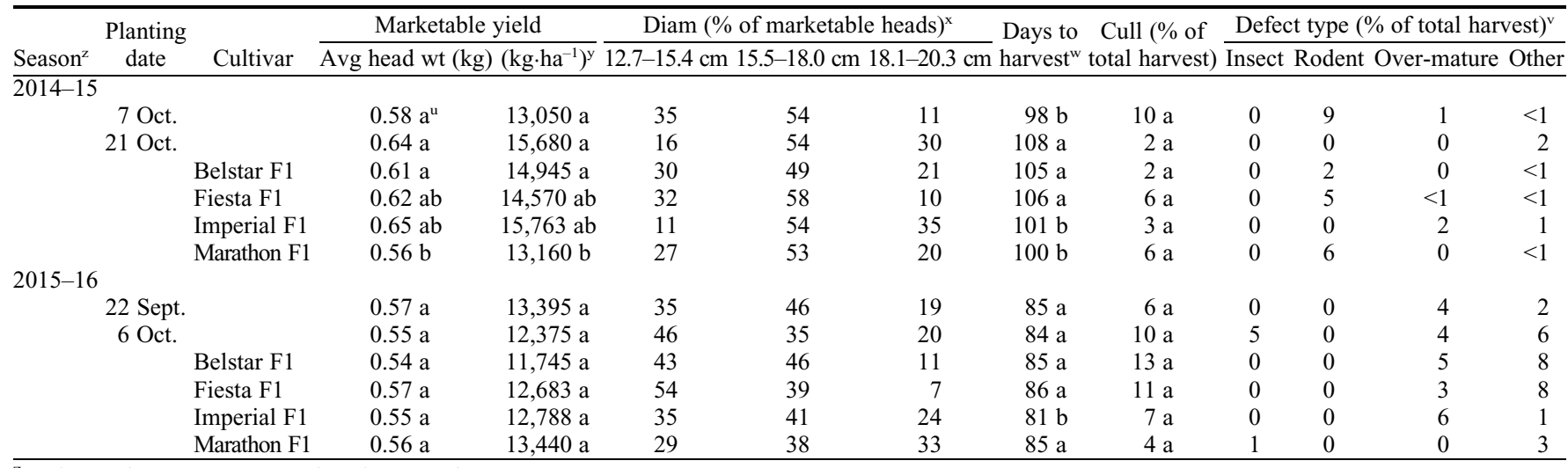

${ }^{\mathrm{z}}$ Each growing season was analyzed separately.

${ }^{\mathrm{y}}$ Marketable yields per plant were extrapolated to 1 ha while assuming that $\approx 70 \%$ of the available area was planted with crops.

${ }^{\mathrm{x}}$ Statistical analysis of marketable head size was not performed but is presented to reflect average head diameter at harvest.

${ }^{\mathrm{w}}$ Average days to harvest after transplanting.

${ }^{\mathrm{v}}$ Statistical analysis of defect type was not able performed because of too few data points but is presented to describe the production management challenges.

"Values followed by the same letter are not significantly different within a column according to Tukey's mean separation test $(P \leq 0.05)$.

Table 5. Comparison of marketable cauliflower yield and days to harvest under high tunnels, 2014-16.

\begin{tabular}{|c|c|c|c|c|c|c|c|c|c|c|c|c|}
\hline \multirow[b]{2}{*}{ Season $^{2}$} & \multirow{2}{*}{$\begin{array}{c}\text { Planting } \\
\text { date }\end{array}$} & \multirow[b]{2}{*}{ Cultivar } & \multicolumn{2}{|c|}{ Marketable yield } & \multicolumn{2}{|c|}{ Diam ( $\%$ of marketable heads) ${ }^{\mathrm{x}}$} & \multirow{2}{*}{$\begin{array}{l}\text { Days to } \\
\text { harvest }^{\mathrm{w}}\end{array}$} & \multirow{2}{*}{$\begin{array}{l}\text { Cull (\% of } \\
\text { total harvest) }\end{array}$} & \multicolumn{4}{|c|}{ Defects $\left(\%\right.$ of total harvest) ${ }^{v}$} \\
\hline & & & (kg/head) & $\left(\mathrm{kg} \cdot \mathrm{ha}^{-1}\right)^{\mathrm{y}}$ & $15.5-18.0 \mathrm{~cm}$ & $18.1-20.3 \mathrm{~cm}$ & & & $\overline{\text { Insect }}$ & Rodent & Over-mature & Other \\
\hline $2014-15$ & 7 Oct. & & $1.16 \mathrm{a}^{\mathrm{u}}$ & $16.820 \mathrm{a}$ & 53 & 47 & $104 a$ & $13 \mathrm{a}$ & 0 & 2 & 10 & 1 \\
\hline & 21 Oct. & & $1.25 \mathrm{a}$ & $19,792 \mathrm{a}$ & 37 & 63 & $108 \mathrm{a}$ & $5 \mathrm{a}$ & 0 & 0 & 4 & 1 \\
\hline & & Amazing & $1.15 \mathrm{~b}$ & $18,209 \mathrm{~b}$ & 48 & 52 & $99 \mathrm{~b}$ & $5 \mathrm{a}$ & 0 & 3 & 2 & 0 \\
\hline & & Snowball Y & $0.86 \mathrm{c}$ & $8,600 \mathrm{c}$ & 63 & 37 & $113 \mathrm{c}$ & $40 \mathrm{~b}$ & 0 & 0 & 34 & 6 \\
\hline 2015-16 & & & & & & & & & & & & \\
\hline & & Denali F1 & $1.46 \mathrm{a}$ & $22,144 \mathrm{a}$ & 22 & 78 & $93 \mathrm{a}$ & $9 \mathrm{a}$ & 0 & 2 & 7 & 0 \\
\hline & & Amazing & $1.41 \mathrm{a}$ & $23,265 \mathrm{a}$ & 16 & 84 & $87 \mathrm{~b}$ & $1 \mathrm{a}$ & 0 & 0 & 1 & 0 \\
\hline & & Snowball Y & $1.12 \mathrm{~b}$ & $9,334 \mathrm{~b}$ & 29 & 71 & $126 \mathrm{c}$ & $50 \mathrm{~b}$ & 0 & 0 & 27 & 23 \\
\hline
\end{tabular}

${ }^{\mathrm{z}}$ Each growing season was analyzed separately.

${ }^{\mathrm{y}}$ Marketable yields per plant were extrapolated to 1 ha while assuming that $\approx 70 \%$ of the available area was planted with crops.

${ }^{\mathrm{x}}$ Statistical analysis of marketable head size was not performed but is presented to reflect average head diameter at harvest.

${ }^{\mathrm{w}}$ Average days to harvest after transplanting.

${ }^{\mathrm{v}}$ Statistical analysis of defect type was not able performed because of too few data points but is presented to describe the production management challenges.

${ }^{\mathrm{u}}$ Values followed by the same letter are not significantly different within a column according to Tukey's mean separation test $(P \leq 0.05)$. 


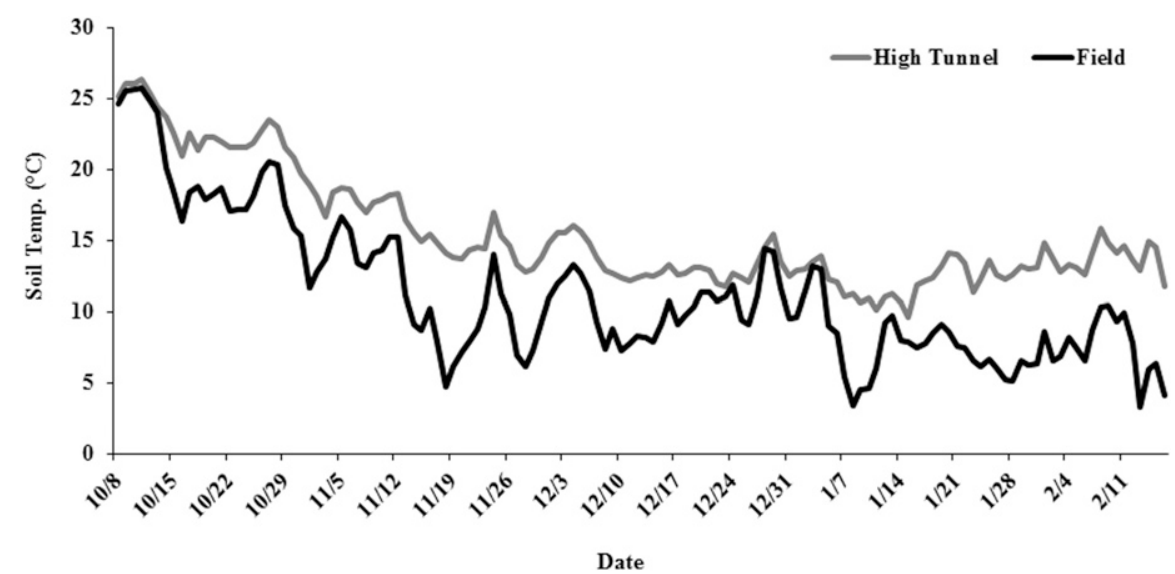

Fig. 1. Average daily soil temperature under high tunnels compared with the open field, 2014-15. *Raised beds under high tunnels were covered in black polypropylene fabric for the entire season. Intermediate weight rowcovers were draped over the crop plants and environmental monitoring stations under the high tunnels but not the open field on nights predicted to be $\leq 0^{\circ}$.

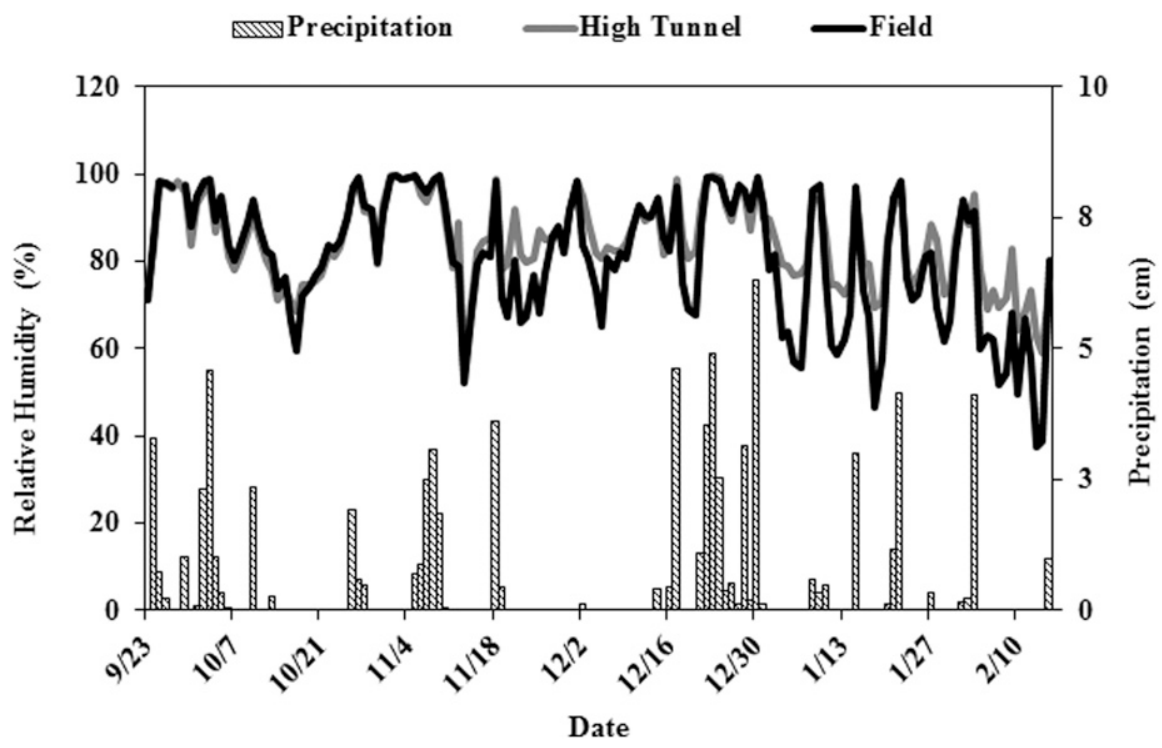

Fig. 2. Average daily relative humidity for high tunnels compared with the open field and total daily precipitation, 2015-16. *Precipitation data were recorded by the GA Automated Environmental Weather Network (http://www.georgiaweather.net/) located $<0.5 \mathrm{~km}$ from the experimental site (UGA Horticulture Research Farm, Oconee County).

or light was the more limiting factor for crop growth in this study. The slowest GDD gains were in January and February which are the coldest and most light limited months in the region. Determining the minimum GDD and DLI for a variety of horticultural crops would be beneficial for high tunnel growers.

According to Maynard and Hochmuth (2007), optimum mean daily temperature for $B$. oleracea plant growth ranges between 15 and $18{ }^{\circ} \mathrm{C}$. Temperature ranges during the month of October for both years during our experiment were within the optimal range but then dropped below it in November and for the remainder of the season. It is possible that increasing the temperature set point for opening our high tunnel sidewalls $\left(>15.6 \pm 1{ }^{\circ} \mathrm{C}\right)$ would have led to more favorable average daily temperatures during the month of November and December across both years.
Most broccoli cultivars also appear to have a quantitative cold requirement or vernalization period to produce flowers (i.e., buds) below $24{ }^{\circ} \mathrm{C}$ which is warmer than many other brassica crops (Fontes et al., 1967; Wurr et al., 1995). We were below these broccoli vernalization thresholds from November through February, but it remains a challenge for regional high tunnel growers to manage daily temperature fluctuations as the crop progresses from vegetative to generative plant growth. An additional complication is managing/optimizing high tunnel temperatures when multiple different crops are grown under a single high tunnel.

Cauliflower crop. Cauliflower yield, quality, and days to harvest were affected by cultivar type but not planting date. 'Denali' and 'Amazing' had high productivity and quality in our high tunnel systems and appear to be suitable cultivars for fall/winter production, but 'Snowball Y' did not perform well. 'Denali' and 'Amazing' produced heads with similar diameters and percent marketability. 'Denali' heads weighed more than 'Amazing' which may provide an advantage in different markets (i.e., weight vs. piece).

In both seasons, most of the crop was harvested during the month of January $\approx 100-110 \mathrm{~d}$ posttransplanting. The actual days to harvest for the 'Amazing' and 'Denali' cauliflower was 20-40 d longer than the seed catalog estimates. The cultivar 'Amazing' was slightly earlier $(\approx 1$ week) to mature compared with 'Denali', which could result in slightly more efficient use of high tunnel space (i.e., less time for a marketable product). These planting dates did not overlap with winter holiday market either year. The extended time may be linked to suboptimal temperatures for plant growth or curd formation and decreased light during the winter months.

Our monthly average air temperatures under the high tunnels were in the optimal vegetative growth range for cauliflower (16 to $18{ }^{\circ} \mathrm{C}$ ) (Smith and Doubrava, 2003) from planting date through the month of October. Similar to broccoli, although lower, many cauliflower varieties require a vernalization period with temperatures between 10 and $16{ }^{\circ} \mathrm{C}$ for curd initiation (Wurr et al.,1993; Grevsen and Olesen, 1994). Our high tunnel systems had air temperatures that fluctuated above and below these vernalization temperatures from December through February. The 'Snowball Y' cultivar appeared much more susceptible to the high tunnel system temperatures than 'Amazing' and 'Denali' which was expressed by increased rates of bracting, riciness (i.e., non-marketable "overmature"), and buttoning and the failure to form heads (i.e., non-marketable "other"). Most of these physiological disorders are attributed to less than optimal temperature regimes (Wurr and Fellows, 1998). Therefore, cultivar selection seems critically important for offseason high tunnel cauliflower production that may be subject to warmer temperatures than the field during critical development phases or more extreme temperature fluctuations.

Microenvironment. There were a number of structural components to our high tunnel system that influenced the microenvironment such as the inflated double-poly roof, polycarbonate end walls, and woven fabric side curtains. In addition, cultural practices employed including using black polypropylene landscape fabric mulch, opening and closing side curtains when ambient temperatures were $>15.6 \pm 1{ }^{\circ} \mathrm{C}$, and using intermediate weight rowcovers when temperatures were predicted to be $\leq 0{ }^{\circ} \mathrm{C}$ likely influenced daily temperatures especially heat gains on cold days and evenings. All of these features were part of our high tunnel system and we did not evaluate their individual effects. Other researchers, for example, have found that heavy weight rowcovers $\left(51 \mathrm{~g} \cdot \mathrm{m}^{-2}\right)$ alone can provide up to $3{ }^{\circ} \mathrm{C}$ on cold evenings 
(Takeda et al., 2008). Conversely, tall side walls (1.8 m openings) and end walls (4.9 m openings) helped ventilate on warm days and keep air temperatures and relative humidity levels near the crop canopy similar to the open field situation.

Overall all broccoli cultivars trialed (i.e., 'Imperial', 'Marathon', 'Belstar', and 'Fiesta') achieved high levels of marketability with frequent harvesting and were faster to reach maturity than cauliflower. Differences of cauliflower yield were more pronounced and demonstrated varying degrees of sensitivity to the high tunnel environment (i.e., 'Denali' and 'Amazing' > 'Snowball Y'). Although high tunnel temperatures over the fall/winter did appear conducive to many cool-season crops, light levels and sensitivity to fluctuating temperatures must be considered along with crop type, cultivar choice, and planting dates. As anticipated, differences in yearly weather patterns influenced both crop yields and days to harvest. Further investigations into the trade-off between slower crop growth during winter (i.e., January and February) for brassica crops alongside market demand (i.e., price premiums, market attraction/retention, etc.) would help determine if these crops are profitable choices for regional growers.

\section{Literature Cited}

Boyhan, G.E., J.W. Gaskin, E.L. Little, E.G. Fonsah, and S.P. Stone. 2016. Evaluation of cool-season vegetable rotations in organic production. HortTechnology 26:637-646.

Carey, E.E., W.J. Lamont, Jr., T.T. Nennich, M.D. Orzolek, and K.A. Williams. 2009. Horticultural crop production in high tunnels in the United States: A snapshot. HortTechnology 19:37-43.

Dufault, R.J. 1997. Determining heat unit requirements for broccoli harvest in coastal South Carolina. J. Amer. Soc. Hort. Sci. 122:169-174.

Fitzgerald, C.B. and M. Hutton. 2012. Production practices and challenges with high tunnel systems in Maine. J. NACAA 5(2): 7 Nov. 2017. <https://www.nacaa.com/journal/index. php?jid=170>.

Fontes, M.R., J.L. Ozbun, and S. Sadik. 1967. Influence of temperature on initiation of floral primordial in green sprouting broccoli. J. Amer. Soc. Hort. Sci. 91:315-320.
Grevsen, K. and J.E. Olesen. 1994. Modelling cauliflower development from transplanting to curd induction. J. Hort. Sci. 69(4): $755-766$.

Gu, S., W. Guan, and J. Beck. 2017. Strawberry cultivar evaluation under high-tunnel and organic management in North Carolina. HortTechnology 27:84-92.

Heather, D.W., J.B. Sieczka, M.H. Dickson, and D.W. Wolfe. 1992. Heat tolerance and holding ability in broccoli. J. Amer. Soc. Hort. Sci. 117:887-892.

Hochmuth, R.C. and D.E. Toro. 2014. Characterization of the Florida fresh fruit and vegetable industry using hydroponic systems or protected agriculture structures. Univ. of FL-IFAS Extension Pub. \#HS1240.

Jayalath, T.C. 2016. The evaluation of high tunnel systems for spring organic lettuce production in Georgia. Univ. of Georgia, Athens, Master's Thesis.

Korcyznski, P., J. Logan, and J.E. Faust. 2002. Mapping monthly distribution of daily light integrals across the contiguous United States. HortTechnology 12:12-16.

Lamont, W.J., Jr. 2009. Overview of the use of high tunnels worldwide. HortTechnology 19:1.

Maynard, D.N. and G.J. Hochmuth. 2007. Knott's handbook for vegetable growers. 5th ed. John Wiley and Sons, Inc., Hoboken, NJ.

National Centers for Environmental Information (NCEI). 1982. Asheville, Climate of Georgia 5 Apr. 2017. <https://www.ncdc.noaa.gov/ climatenormals/clim60/states/Clim_GA_01. pdf $>$.

NRCS-USDA. 1968. Soil survey of Clarke and Oconee Counties of Georgia. 1 June 2014. <http:// www.nrcs.usda.gov/Internet/FSE_MANUSCRIPTS/ georgia/clarke_oconeeGA1968/CO.pdf>.

O'Connell, S., C.L. Rivard, M.M. Peet, C. Harlow, and F. Louws. 2012. High tunnel and field production of organic heirloom tomatoes: Yield, fruit quality, disease and microclimate. HortScience 47:1283-1290.

Ogden, A.B. and M.W. van Iersel. 2009. Southern highbush blueberry production in high tunnels: Temperatures, development, yield, and fruit quality during the establishment years. HortScience 44:1850-1856.

Sanchez, E., T. Butzler, L. Stivers, R. Pollock, T. Elkner, S. Bogash, and W. Lamont. 2016. Performance of broccoli cultivars in spring and fall evaluations in Pennsylvania. HortTechnology 26:869-876.

Salame-Donoso, T.P., B.M. Santos, C.K. Chandler, and S.A. Sardent. 2010. Effect of high tunnels on the growth, yields, and soluble solids of strawberry cultivars in Florida. Intl. J. Fruit Sci. 10(3):249-263.

Smith, P. and N. Doubrava. 2003. Cauliflower \#HGIC 1326 Clemson University Coop. Expt. 27 June 2017. <http://www.clemson.edu/ extension/hgic/plants/pdf/hgic1326.pdf $>$.

Takeda, F., K. Demchak, M.R. Warmund, D.T Handley, R. Grube, and C. Feldhake. 2008. Rowcovers improve winter survival and production of western trailing 'Siskiyou' blackberry in the eastern United States. HortTechnology 18:575-582.

USDA. 2012a. USDA plant hardiness zone map. 24 Aug. 2015. <http://planthardiness.ars.usda. gov/PHZMWeb/>.

USDA. 2012b. More communities warm up to winter markets. Release No. 0352.12. 14 Sept. 2016. <https://www.usda.gov/media/pressreleases/2012/12/06/more-communities-warmwinter-markets $>$

US Government Publishing Office. 1990. 7 U.S. Code \$6507-State organic certification program. 22 Aug. 2015. <http://www.gpo.gov/ fdsys/granule/USCODE-2011-title7/USCODE2011-title7-chap94-sec6507>

USNO. 2015. (U.S. Naval Observatory). 16 May 2017. <http://aa.usno.navy.mil/data/docs/Dur OneYear.php>.

Wallace, R.W., A.L. Wszelaki, C.A. Miles, J.S. Cowan, J. Martin, J. Roozen, B. Gundersen, and D.A. Iglis. 2012. Lettuce yield and quality when grown in high tunnel and open-field production systems under three diverse climates. HortTechnology 22:659668.

Wells, O.S. and J.B. Loy. 1993. Rowcovers and high tunnels enhance crop production in the northeastern United States. HortTechnology 3:92-95.

Wittwer, S.H. and N. Castilla. 1995. Protected cultivation of horticultural crops worldwide. HortTechnology 5:6-23.

Wurr, D.C.E., J.R. Fellows, K. Phelps, and R.J. Reader. 1993. Vernalization in summer/ autumn cauliflower (Brassica oleracea var. botrytis L.). J. Expt. Bot. 44(9):1507-1514.

Wurr, D.C.E., J.R. Fellows, K. Phelps, and R.J. Reader. 1995. Vernalization in calabrese (Brassica oleracea var. italica)-a model for apex development. J. Expt. Bot. 46(10):14871496.

Wurr, D.C.E. and J.R. Fellows. 1998. Leaf production and curd initiation of winter cauliflower in response to temperature. J. Hort. Sci. Biotechnol. 73(5):691-697. 